\title{
The effects of raking Irish moss (Chondrus crispus) on lobsters in Prince Edward Island
}

\author{
D. J. Scarratt \\ Fisheries Research Board of Canada; St. Andrews, N. B., Canada
}

EXTRAIT: Effets, de la récolte de «mousse d'Irlande» (Cbondrus crispus) sur les homards, dans l'tle du Prince-Edouard. Quatre méthodes principales furent utilisées pour évaluer le dommage causé aux stocks de homards par la récolte de Chondrus crispus: l'observation depuis les bateaux équipés à cette fin; l'examen, par des plongeurs, des secteurs prospectés et de la densité des peuplements de homards; l'observation sousmarine des rateaux en mouvement et des réactions provoquées sur les homards (Homarus americanus); l'examen des traces creusées par les rateaux et des homards qui s'y trouvaient. Sur les fonds de mousse lisses les peuplements de homards étaient peu denses et les dommages causés par récolte de mousse étaient sans importance. Sur les fonds modérément raboteux l'abondance des homards est estimée à 600 par hectare; approximativement $2 \%$ des homards récoltés sur les traces des rateaux étaient tués à chaque passage. Sur les fonds très raboteux, l'abondance des homards dépassait 1000 par hectare; $5,2 \%$ des homards récoltés sur les traces des rateaux étaient tués. Une récolte intensive de mousse est estimée entraîner la perte de 280 homards par bateau et par jour; il s'y ajoute d'autres dommages, tels que la perte des pinces ou les blessures qui abaissent le taux de croissance et la valeur commerciale. La taille moyenne des homards tués était de $35 \mathrm{~mm}$ pour la longueur de la carapace (environ $100 \mathrm{~mm}$ de longueur totale); ces homards auraient été commercialement exploitables dans un délai de deux ans, et auraient alors la valeur d'environ 8 "cents» canadiens pièce. La perte totale causée à ces fonds raboteux fut évalué à $36.000 \$$, somme correspondant à 16-20\% de la valeur de la récolte de mousse, ou à $7 \%$ de la valeur annuelle de la récolte de homards dans ce secteur. Ces chiffres sont suffisamment élevés pour justifier un examen critique des efforts consacrés à la récolte de mousse.

\section{INTRODUCTION}

The seaweed harvest from the Canadian Atlantic Ocean has increased in value from $\$ 50,000$ in the 1940 's to about $\$ 3$ million in 1970 . The principal species is Irish moss (Chondrus crispus) which grows from LWM to $6-8 \mathrm{~m}$ in a number of rocky areas. Approximately half the harvest is from Prince Edward Island (P.E.I.) where, originally, moss dislodged by wave action was gathered off the beach or in the surf. Alternatively, a hand rake was used to "comb" moss off the rocks. Since the early 1960's the hand rake has been modified and mechanized. Rakes are now up to $3 \mathrm{~m}$ wide, weighing up to $100 \mathrm{~kg}$, and are towed on steel cables by power boats at speeds to $2 \mathrm{knots}(1 \mathrm{~m} / \mathrm{sec})$. In western P.E.I. (Fig. 1), this rake is now the principal harvesting method. In eastern P.E.I., the presence of the more delicate commercially valuable 
weed Furcellaria fastigiata among the moss, has inhibited the development of drag raking as a harvesting method.

All areas where Chondrus crispus grows are also fished for lobsters. Thus it was inevitable that the spread of drag raking for Irish moss would be opposed by conservation-minded lobster fishermen. The question of damage to lobsters (Homarus americanus) by moss raking first arose in eastern Prince County, P.E.I., where rakers observed that crushed lobsters or parts of lobsters were being found in the rakes and

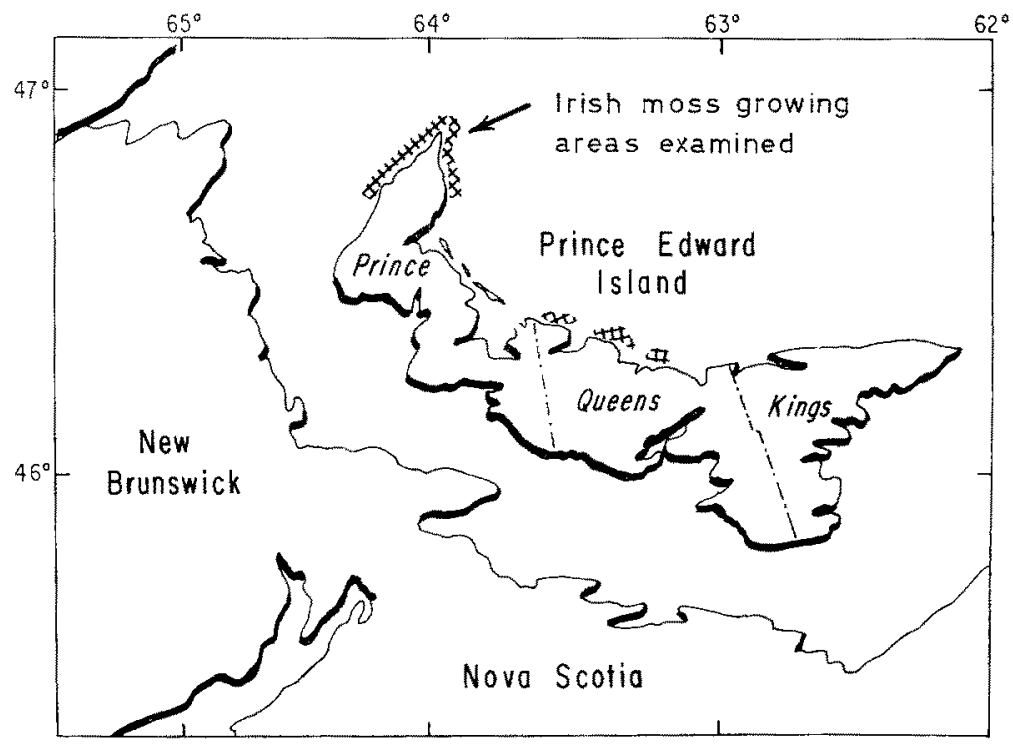

Fig. 1: Irish moss growing areas of Prince Edward Island (Canada) examined in 1970 and 1971

speculated that more damage was being caused than was actually seen. Observations aboard commercial boats, and under water, suggested the total damage was inconsequential and raking was permitted to continue.

The spread of raking into the north shore of Queens County, P.E.I., in 1969 was vigorously opposed by local lobster fishermen. More lobsters were seen in moss rakes here than in areas further west and fishermen believed that serious damage would result if raking were allowed to continue. An investigation was initiated in May, 1970. It sought to compare the damage observed aboard commercial moss rakers on different grounds, and using diving techniques, to investigate the numbers of lobsters on moss beds, their reactions to raking, and the numbers killed or damaged. This would enable the effects of moss raking to be explained and predicted, and the probable costs (in dollars) compared with profits to fishermen.

This paper summarizes results of the 1970 and 1971 investigations. A more detailed report will be published elsewhere. 


\section{METHODS}

\section{Observations aboard commercial moss raking vessels}

An observer accompanied moss boats selected at random from a number of ports in Prince and Queens Counties. A full count was kept of all tows made each day. Moss landings were estimated or the weight obtained from buyers' records. In 1970, a few tows were timed by stop-watch and crude estimates of towing speed made by stopwatch timing chips of wood past measured distances along the boat's side. Lobsters, or parts of lobsters recovered from the moss, were measured with a vernier caliper.

In 1971, following repeated lobbying by lobstermen's associations, a temporary ban was imposed on moss raking in Queens County which restricted observations to Prince County boats. Similar records were kept, except that each day ten tows were timed and ten estimates of towing speed were made using a modified ship's log. It was assumed that boat speed would give a reasonable estimate of rake speed, hence distance travelled and area raked could be calculated.

\section{Lobster abundance estimates}

Selection of sampling sites in 1970 was made following survey of the moss beds from a manned, towed underwater sled (Foulkes \& SCARratT 1972). A section of moss bed, $300 \mathrm{~m}$ long, was selected and marked off as an experimental zone from which commercial rakers were excluded.

Initial lobster abundace estimates were made by divers counting and collecting all lobsters found within a $20.8 \mathrm{~m}^{2}$ area enclosed within a square folding metal frame, which was set four times at each station (SCARrATt 1968). Later, an improved method was developed using two $50 \mathrm{~m}$ long lead-cored lines laid individually at each station. Divers, carrying a metal rod, $1 \mathrm{~m}$ long, collected all lobsters within a metre of one side of each line. Each station was thus $100 \mathrm{~m}^{2}$. Notes were made of depth, bottom type, identity and abundance of seaweeds and major fauna.

\section{Reaction of lobsters to moving rakes}

Initially, two standard $3 \mathrm{ft}(0.9 \mathrm{~m})$ rake units were rigged together with a polypropylene rope bridle. Later this bridle was replaced by chain slings and a steel-pipe spreader bar to which the rake units were shadkled, thus duplicating commercial practice. A $12 \mathrm{~mm}$ diameter polypropylene line, $5 \mathrm{~m}$ long, knotted at intervals, was fastened to the end of the tow rope. A diver entered the water holding this rope with the boat moving. The rakes were pushed overboard and the tow rope paid out. Once the rake started moving, the diver noted lobsters seen in, or escaping from, the path of the rake. Count was kept of those that: (a) avoided the rake completely; (b) touched or were hit by the rake but were uninjured; (c) lost legs or claws or suffered minor injuries; (d) were killed outright or so seriously wounded that survival was unlikely. 
Each tow was 3 minutes long. After each tow, the diver reported lobsters seen to an assistant on deck. Usually 12 tows were observed in sequence.

\section{Rake track examination}

To determine whether more lobsters were killed or injured than were seen by observers, sections of rake track approximately $100 \mathrm{~m}^{2}$ in area were examined. Leadcored, braided nylon lines, $50 \mathrm{~m}$ long, weighted and buoyed at one end, were threaded through guides welded on each side of the rake. Buoys, weights, and rake were pushed off the stern of the boat in sequence and the lines paid out to mark each side of the track which was about $2 \mathrm{~m}$ wide. Divers began to examine the track immediately the lines had cleared the guides. Lobsters observed between the lines were collected and examined.

\section{Towing speed calibration}

Survey boat towing speed was adjusted by experience to match commercial practice. In 1970, a number of tows were timed past marks set $50 \mathrm{~m}$ apart to give a more accurate estimation of raking speed, and in 1971 a number of timed tows were made with an odometer wheel fastened to the rake and connected to an event recorder on deck. Raking speeds so estimated were compared with boat speeds estimated with the ship's $\log$.

\section{RESULTS AND ANALYSIS}

\section{Observations aboard moss raking boats}

Rake sets are normally rigged with two or three standard $3 \mathrm{ft}(0.9 \mathrm{~m})$ units on a spreader bar. Boats with two sets of rakes normally work them alternately so that one

Table 1

Summarized observations aboard moss raking boats in 1970 and 1971.

Tow speed and duration are based on 10 observations per day's raking

\begin{tabular}{|c|c|c|c|c|c|c|c|}
\hline Year & County & $\begin{array}{c}\text { Days } \\
\text { observed }\end{array}$ & $\begin{array}{c}\text { Mean } \\
\text { tows } \\
\text { (per day) }\end{array}$ & $\begin{array}{c}\text { Mean } \\
\text { tow } \\
\text { time } \\
\text { (sec) }\end{array}$ & $\begin{array}{c}\text { Speed } \\
(\mathrm{cm} / \mathrm{sec})\end{array}$ & $\begin{array}{l}\text { Mean wt } \\
\text { moss } \\
\text { landed } \\
(\mathrm{kg})\end{array}$ & $\begin{array}{l}\text { Total no. } \\
\text { lobsters } \\
\text { seen }\end{array}$ \\
\hline \multirow[t]{3}{*}{1970} & W. Prince & 8 & 136 & - & $70^{*}$ & 745 & 2 \\
\hline & E. Prince & 2 & 167 & $128^{*}$ & $85^{*}$ & 1410 & 2 \\
\hline & Queens & 11 & 166 & $130 * \%$ & $88^{2 * * *}$ & 1680 & $25^{+}$ \\
\hline \multirow{2}{*}{1971} & W. Prince & 12 & 128 & 218 & 85 & 795 & 4 \\
\hline & E. Prince & 7 & 166 & 224 & 91 & 805 & 7 \\
\hline
\end{tabular}


Table 2

Mean number of lobsters seen per day in commercial moss rakes

\begin{tabular}{|lcc|}
\hline County & 1970 & 1971 \\
\hline W. Prince & 0.25 & 0.33 \\
E. Prince & 1.0 & 1.0 \\
Queens & $2.5^{*}$ & no raking \\
$*$ Excludes those taken uninjured in baskets. & \\
\hline
\end{tabular}

is being set for raking while the other is being hauled back for the moss to be removed. On good moss grounds, rakes fill rapidly and tow duration is determined by the time taken to clean rakes. On poor or marginal grounds, tow duration increases. Some boats fit wire mesh baskets to the rakes to catch dislodged moss.

Twenty-one days' observations were made in 1970 and 19 days' observations in 1971 (Table 1). Mean boat speed was about $85-90 \mathrm{~cm} / \mathrm{sec}$. Mean tow duration in 1970 was 2 minutes 10 seconds, and in 19713 minutes 40 seconds. Boats made on average about 150 tows per day. Most lobsters were seen per day in Queens County and fewest in W. Prince County (Table 2). The mean estimated size of 44 lobsters found in rakes in 1970 was $44.4 \pm 8.8 \mathrm{~mm}$ carapace length. All were below the minimum legal size limit of $63.5 \mathrm{~mm}$ carapace length (c.l.).

\section{Lobster abundance}

Lobster abundance was lowest on the smooth, flat bedrock ledges off W. Prince County, higher on the medium rough moss beds off E. Prince County, and highest on the heavily boulder strewn Queens County beds (Table 3). The Queens County beds

Table 3

Lobster abundance estimates and mean carapace length at sample stations in 1970 and 1971

\begin{tabular}{|llccc|}
\hline County & Dates & $\begin{array}{c}\text { Stations } \\
\text { worked }\end{array}$ & $\begin{array}{c}\text { Lobsters } \\
\left(\text { no. } / 100 \mathrm{~m}^{2}\right)\end{array}$ & $\begin{array}{c}\text { Mean carapace } \\
\text { length } \\
\text { (mm) }\end{array}$ \\
\hline Queens & 1970 & & & \\
& May/June & 6 & $4.2^{*}$ & 37.7 \\
& June & 14 & 10.9 & 39.4 \\
July & 15 & 9.4 & 39.2 \\
W. Prince & July & & & \\
E. Prince & June & 29 & 0.7 & 39.5 \\
Queens & July & 9 & 5.8 & 42.4 \\
& June & 12 & 6.3 & 39.0 \\
& July & 8 & 10.3 & 38.6 \\
* Based on 100 $\mathrm{yd}^{2}$ samples. & 8 & & \\
\hline
\end{tabular}


also showed increase in lobster abundance on moss beds from spring to summer. At the time of year when moss raking was, or would have been, at its peak, lobster abundance on Queens County beds averaged $9.4 / 100 \mathrm{~m}^{2}$. There were no differences in lobster abundance between stations sampled in 1970 inside the zone closed to commercial raking and those sampled outside (SCARratT MS 1971). Mean size of lobsters on moss beds was between 38 and $42 \mathrm{~mm}$ c.l.

\section{Damage observed from moving rakes}

One hundred and eighty-nine 3-min tows were observed by divers riding the rope-bridled rake (Table 4). Damage observed was less than that seen in 165 diverobserved tows with the chain-bridled rake, suggesting that the heavier, noisier chainbridled rake with its heavy spreader bar is more lethal to lobsters. A series of tows

Table 4

Lobsters observed by divers during 3-minute rake tows in 1970 and 1971

\begin{tabular}{|c|c|c|c|c|c|c|c|c|}
\hline & \multirow{2}{*}{\multicolumn{2}{|c|}{ Year and series }} & \multicolumn{6}{|c|}{ Numbers of lobsters } \\
\hline & & & $\begin{array}{c}\text { Tows } \\
\text { number }\end{array}$ & $\begin{array}{l}\text { Avoid } \\
\text { rake }\end{array}$ & $\begin{array}{c}\text { Hit } \\
\text { un- } \\
\text { damaged }\end{array}$ & $\begin{array}{c}\text { Light } \\
\text { wound }\end{array}$ & $\begin{array}{l}\text { Killed } \\
\text { crushed }\end{array}$ & Total \\
\hline (a) & Rope- & bridled rake: & & & & & & \\
\hline & 1970 & Queens County & 189 & 496 & 472 & 24 & 13 & 1005 \\
\hline (b) & Chain & -bridled rake: & & & & & & \\
\hline & 1970 & Queens County & & & & & & \\
\hline & & slow tows & 24 & 102 & 82 & 6 & 2 & 192 \\
\hline & & fast tows & 24 & 79 & 78 & 6 & 8 & $17 \overline{1}$ \\
\hline & & Queens County & 48 & 84 & 120 & 23 & 4 & 231 \\
\hline & 1971 & E. Prince County* & 9 & 35 & 27 & 7 & 2 & 71 \\
\hline & 1971 & Queens County & 60 & 177 & 398 & 37 & 7 & 619 \\
\hline & & Sub-total & 165 & 477 & 705 & 79 & 23 & 1284 \\
\hline
\end{tabular}

with alternating slow and fast haul-back showed that higher rake speeds caused significantly more observable damage. The majority of lobsters seen avoided the rake or escaped injury but subsequent calculation showed that only a fraction (19-72\%) of those estimated to be in the path of the rake had been seen to respond (Table 5). The fate of lobsters not seen could not be determined by this method. Many boulders were rolled or displaced by the rakes and a high proportion of the moss cut was not collected.

\section{Examination of rake tracks}

Twenty-five fresh, $50 \mathrm{~m}$ long, rake tracks were examined in August and September, 1970 (Table 6). T'welve were on commercially raked grounds and 13 were on the closed zone. A total of 13 freshly killed lobsters was found out of 225 examined. Many 
Table 5

Lobster population density, no. $/ 100 \mathrm{~m}^{2}$ estimate of lobsters in the path of rake, mean numbers observed during 3-minute tow, and mean numbers recovered from $100 \mathrm{~m}^{2}$ rake tracks

\begin{tabular}{|c|c|c|c|c|c|}
\hline Date & County & $\begin{array}{l}\mathrm{No} / 100 \mathrm{~m}^{2} \\
\text { lobster } \\
\text { population }\end{array}$ & $\begin{array}{l}\text { Estimated } \\
\text { number } \\
\text { in path }\end{array}$ & $\begin{array}{l}\text { Mean number } \\
\text { observed } \\
\text { per tow }\end{array}$ & $\begin{array}{c}\text { Mean number } \\
\text { in rake track } \\
100 \mathrm{~m}^{2}\end{array}$ \\
\hline $\begin{array}{l}1970 \\
\text { July }\end{array}$ & & \multirow{3}{*}{9.4} & \multirow{2}{*}{$29.6 *$} & & \\
\hline August & Queens & & & $\begin{array}{l}5.3 \text { rope bridle } \\
7.5 \text { chain bridle }\end{array}$ & 9.0 \\
\hline September & Queens & & & 4.8 & 9.0 \\
\hline 1971 & & & & & \\
\hline July & E. Prince & 5.8 & $11.0^{*} \%$ & 7.9 & 6.2 \\
\hline July & Queens & 8.5 & $24.3^{* \cdots *}$ & 8.6 & 6.6 \\
\hline August & Queens & 10.3 & $29.4 \%$ & 12.9 & $\begin{array}{l}8.0 \\
4.8+\end{array}$ \\
\hline September & Queens & & & & $\begin{array}{c}5.6 \\
10.0+\end{array}$ \\
\hline
\end{tabular}

Table 6

Lobsters observed in fresh $50 \mathrm{~m}$ long rake tracks

\begin{tabular}{|c|c|c|c|c|c|c|c|c|c|}
\hline \multirow[b]{2}{*}{ Year } & \multirow[b]{2}{*}{ County } & \multirow[b]{2}{*}{$\begin{array}{c}\text { Number } \\
\text { of } \\
\text { tracks }\end{array}$} & \multicolumn{7}{|c|}{ Numbers of lobsters } \\
\hline & & & $\begin{array}{l}\text { Not } \\
\text { exam- } \\
\text { ined }\end{array}$ & $\begin{array}{l}\text { Undam- } \\
\text { aged }\end{array}$ & $\begin{array}{c}\text { Missing } \\
\text { claws }\end{array}$ & $\begin{array}{c}\text { Old } \\
\text { wounds }\end{array}$ & $\begin{array}{l}\text { New } \\
\text { wounds }\end{array}$ & Dead & Total* \\
\hline \multirow[t]{2}{*}{1970} & Queens & $13^{* \div *}$ & 2 & 68 & 21 & 3 & 4 & 6 & 102 \\
\hline & & $12 * *$ & 1 & 74 & 32 & 3 & 5 & $8^{+}$ & 123 \\
\hline \multirow{4}{*}{1971} & E. Prince & 17 & 8 & 80 & 12 & 6 & 1 & 2 & 106 \\
\hline & $\begin{array}{l}\text { Queens } \\
\text { (Iuly) }\end{array}$ & 50 & 17 & 218 & 61 & 27 & 28 & 7 & 350 \\
\hline & Queens & $17++$ & 4 & 77 & 26 & 11 & 7 & 0 & 119 \\
\hline & Queens & $9^{+++}$ & 0 & 44 & 8 & 3 & 4 & 2 & 59 \\
\hline \multicolumn{10}{|c|}{$\begin{array}{l}\text { Total is of number of lobsters in tracks. It may include lobsters with more than one type } \\
\text { of wound; } \text { Within area closed to fishermen; } \\
\text { lobster partly consumed by amphipods; ++ Tows made before intensive raking; }+++ \text { Tows } \\
\text { made after intensive raking. }\end{array}$} \\
\hline
\end{tabular}

had been crushed between boulders rather than hit by the rake. There were no differences between the areas open and closed to commercial raking. Lobster abundance on Queens County moss beds at this time of year is about $10 / 100 \mathrm{~m}^{2}$, therefore 13 lobsters killed represent $5.2 \%$ of the exposed population.

In 1971 in E. Prince County in 17 tracks, two dead lobsters were found, which represent about $2 \%$ of the 99 estimated to be in the rake path. In 50 tracks examined in Queens County in July, 1971, after the ban on raking had been imposed, only seven 
dead lobsters were found out of 350 examined. From lobster abundance estimates, the number expected in 50 tracks is 425 . The seven dead lobsters represent $1.6 \%$ of the theoretical population in the rake path. This is significantly lower than the $5.2 \%$ observed in 1970 when commercial raking was in progress.

To explore the effect of intensive raking on Queens County beds, a number of tracks were examined in a small area, the area was then raked for 2-3 hours and then more tracks were examined (Table 6 ). The numbers are small but observed mortality (2/59) after intensive raking was higher than before $(0 / 119)(Z=2.4, p=0.016)$. This suggests that raking mortality in undisturbed populations is lower than in heavily raked populations and confirms the higher mortality estimate for Queens County in 1970.

The mean carapace length of lobsters found killed in rake tracks was $35 \mathrm{~mm}$. The high incidence of claw loss (up to $25 \%$ ) and wounding in these small lobsters is possibly due to raking but also partly to winter ice conditions.

\section{Natural mortality and value of lobsters}

The value of legal-sized lobsters before capture is the product of market price and lobster weight. Sub-legal lobsters, having no legitimate market, only have a potential value based on the probability of their survival to legal size. From WILDER (1953) it is possible to estimate that $35 \mathrm{~mm}$ lobsters in this area are two years from entering the

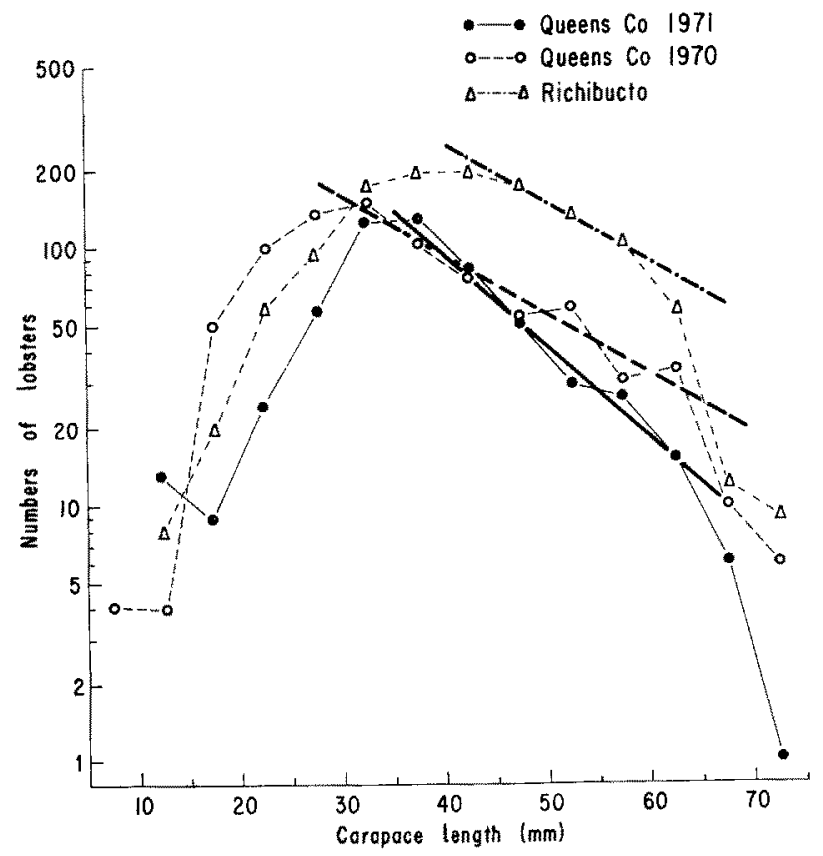

Fig. 2: Size frequency curves of hand caught lobsters 
fishery. D. E. AIKEN (personal communication) corroborates this with data showing that $50-55 \mathrm{~mm}$ c.l. lobsters moult twice per year with an average annual increment of $15 \mathrm{~mm}$.

Semi-log size frequency plots of 1238 lobsters hand collected at Richibucto, N.B., 818 lobsters collected off Queens County moss beds in 1970 and 861 collected in 1971 gave mortality estimates over $15 \mathrm{~mm}$ increments of $54 \%, 56 \%$ and $70 \%$, respectively (Fig. 2). The 1971 annual mortality value of $70 \%$ followed extremely heavy raking the year before; therefore, it is reasonable to deduce that normal annual mortality is about $55 \%$. The average value of commercial Queens County lobsters is about $40 \mathrm{c}$ each, therefore the value of $35 \mathrm{~mm}$ lobsters is about $8 \mathrm{c}$ each.

\section{Estimate of damage attributable to raking in Queens County}

According to FFRENCH (1971), 25 boats worked the Queens County beds in 1970 for an average season of 65 working days each. From data in Table 1, each boat would rake between 3.8 to 5.7 hectares (double or triple rakes) at $130 \mathrm{sec}$ mean tow duration or 6.4 to 9.6 ha per day at $220 \mathrm{sec}$ tow duration.

The number of lobsters in 5.7 ha is about 5,360 of which $5.2 \%$ or 280 might be killed. If each lobster has an average value of $8 \mathrm{c}$, damage by each raker per day can be estimated at $\$ 22.36$ with a fleet season total of $\$ 36,000$.

Analysis of buyer's records shows $74 \%$ of moss harvested in 1970 was landed by rakers. The season's total was worth $\$ 268,250$ of which $\$ 198,000$ can be attributed to raking. Lobster landings in 1970 were $\$ 514,000$ (official statistics). Thus a damage estimate of $\$ 36,000$ is equivalent to $18 \%$ of the moss raked or $7 \%$ of the lobsters landed.

\section{CONCLUSIONS}

Damage to lobsters by moss raking is related to the roughness of the beds and lobster abundance on them, the type of rake used, and the speed of towing. On smooth beds, lobster populations are low and mortality negligible. On rough grounds, lobster populations are high and damage to them justifies some control of raking activities.

\section{SUMMARY}

1. The number of damaged lobsters (Homarus americanus) seen aboard commercial moss raking boats varies with the abundance of lobsters on the grounds, but is low in comparison with the numbers known to be damaged.

2. Lobster abundance is highest on rough, boulder strewn moss beds, and lowest where beds are smooth.

3. Some lobsters are seen to escape from the path of the rake unharmed. The proportion avoiding the rake is lowest on rough grounds, and highest on smooth grounds. 
4. Examination of rake tracks in heavily raked areas shows that up to $5.2 \%$ of lobsters in the path may be killed by each passage of the rakes.

5. Up to 280 lobsters, average size $35 \mathrm{~mm}$ carapace length, average value $8 \mathrm{c}$ each, may be killed by one moss raking boat in one day. More lose claws or are wounded.

6. Total value of lobsters killed by all rakers in one area is $\$ 36,000$ which is $18 \%$ of landed value of moss or $7 \%$ of lobster landings.

7. Some control of moss raking is justified.

Acknowledgements. I am indebted to Messrs. A. J. Wilson, L. A. Giguere, K. M. MontgOMERY, G. Hargrayes, and R. GeORGe for assistance diving and with observations aboard commercial fishing boats; to Mr. C. WALLACE for furnishing the experimental moss rake; to the commercial fishermen who allowed us to work aboard their boats, and to Drs. D. G. WILDER and J. C. MEDCOF for their helpful criticism of this manuscript.

\section{LITERATURE CITED}

FrRench, R. A., 1971. A current appraisal of the Irish moss industry. Dept. Fish. Forestry, Ottawa, $230 \mathrm{pp}$.

Foulxes, T. J. \& SCarratT, D. J., 1972. Design and performance of TURP - a diver controlled towed underwater research plane. Tech. Rep. Fish. Res. Bd Can. 295, 1-15.

SCARRATt, D. J., 1968. An artificial reef for lobsters (Homarus americanus). J. Fish. Res. Bd Can. 25, 2683-2690.

- 1971. Investigation into the effects of Irish moss raking on lobsters. MS Rep. Ser. Fish. Res. Bd Can. 1105, 1-36.

WIIDER, D. G., 1953. The growth rate of the American lobster (Homarus americanus). J. Fish. Res. Bd Can. 10, 371-412.

Author's address: Dr. D. J. ScarratT

Fisheries Research Board of Canada

St. Andrews, N. B.

Canada 